\title{
Intertemporal current account sustainability in the presence of structural breaks ${ }^{* 1}$
}

\author{
Miomir Jakšić ${ }^{2}$, Nikola Fabris ${ }^{3}$, Milutin Ješic ${ }^{4}$
}

\begin{abstract}
We examined the hypothesis of current account sustainability in Czech Republic, Hungary, Poland and Serbia. Our motivation for the research study has grown from the deficiency of similar kind of studies for these countries in the observed period. This is important because of the investigation of recent global crisis consequences. The backbone for the research can be found in Hakkio and Rush (1991) and Husted (1992). However, we employed different methodological tools with a purpose to include the possibility of structural breaks. The crucial idea is to empirically test current account sustainability through the concept of cointegration between export and import. In the last decades, substantial progress has been made in econometric modeling, which has shown that conclusions derived from standard tests can be inadequate in the presence of structural breaks. We want to check this hypothesis by application of new approaches. Unit root tests were applied on observed variables. After that, Gregory-Hansen approach was employed with purpose of cointegration presence testing. Finally, we estimated cointegration vectors. The main finding of the research study is that there is some
\end{abstract}

* Received: 03-09-2018; accepted: 06-12-2018

1 This work has been supported by Serbian Ministry of education, science and technological development under the project "The role of state in the new model of growth of Serbia's economy" (179065).

2 Full professor, University of Belgrade, Faculty of Economics, Kamenička 6, 11000 Belgrade, Serbia. Scientific affiliation: macroeconomic theory and institutions. Phone: +381113021079. Fax: +381112639560. E-mail: mjaksic@ekof.bg.ac.rs. Personal web-site: http://www.ekof. bg.ac.rs/miomir-jaksic-phd/?lang=en.

${ }^{3}$ Full professor, University of Belgrade, Faculty of Economics, Kamenička 6, 11000 Belgrade, Serbia. Scientific affiliation: macroeconomic theory and monetary policy. Phone: +381113021086. Fax: +381112639560. E-mail: fnikola@ekof.bg.ac.rs. Personal web-site: http://www.cbcg.me/slike_i_fajlovi/fajlovi/html/nikola_fabris.html.

4 Teaching Assistant, University of Belgrade, Faculty of Economics, Kamenička 6, 11000 Belgrade, Serbia. Scientific affiliation: macroeconomic theory and policy. Phone: +381113021097. Fax: +381112639560. E-mail: milutinjesic@ekof.bg.ac.rs. Personal web-site: http://www.ekof. bg.ac.rs/milutin-jesic/?lang=en (corresponding author). 


\begin{abstract}
form of the current account sustainability in all of the observed countries. In Czech Republic and Hungary, it is stronger, while in Poland and Serbia it is weak. Therefore, policymakers have to significantly improve competitiveness with the purpose of strengthening external stability. This paper extends current literature, since new methodological frameworks are used and new countries or new period samples were analyzed.
\end{abstract}

Key words: current account, intertemporal approach, structural breaks

JEL classification: C13, F32, F41

\title{
1. Introduction
}

Due to the external imbalances in many countries in recent decades, the issue of current account (CA) sustainability has been revived in the economic literature as one of the most interesting topics for research. Aristovnik (2006) pointed out that CA sustainability is very important from political and economic aspect. The vulnerability of countries to external shocks, currency crises, and fiscal irresponsibility is high. For these reasons it is important to identify, monitor and resolve all potential triggers of external position unsustainability. However, external position is empowered by increase in competitiveness, and in order to make competitiveness permanent, the usage of resources has to be effective (Boronenko and Drezgić, 2014, p. 49). Certainly, many conditions have to be met, but one of the most important preconditions is to fulfill the intertemporal constraint.

The empirical testing of fulfillment of CA sustainability has been experiencing its grown since the 1990s. This type of research, however, has been carried out mainly in developed countries. Insufficiently long time series for reliable statistical inference and inadequate data quality are the main limitations to such research in developing countries.

The first papers that constitute used methodological approach are related to the fiscal sphere. Trehan and Walsh (1988) analyzed the preconditions necessary to comply with the budget constraint. They first proposed theoretical postulates and after that empirically tested the cointegration between revenues and expenditures in the US. Hakkio and Rush (1991) used the cointegration approach to investigate the problem of fiscal sustainability, too. They put special emphasis on the possibility of marketing the debt. The methodology of cointegration in the sphere of CA sustainability is implemented in the research later. Some adjustments have to be made. The backbone for this research can be found in papers that initialize and develop methodology of testing the CA sustainability from intertemporal perspective. Husted (1992) tried to find the origins of the history of US external imbalances by identifying the "long-run tendency" of the CA balance. Apergis et al. (2000) found evidence in favor of sustainability in the case of Greece and in support of unnecessary devaluation of currency. Afonso et al. (2017) analyzed 
the sustainability of the CA balance in a sample of EU countries by two different approaches. First, they use unit root tests of CA balance-to-GDP ratios and cointegration tests of exports and imports of goods and services. After that, they used a dynamic external debt constraint in order to compute the trade balance that stabilizes the net international investment position over a given period. These papers have raised the motivation and space for the deeper analysis of this problem in different context.

From the econometric methodology side, the backbone for the research was set up by introduction of tests that account for structural breaks. After determination of the integration level of the export and import series, by the most common tests, but also by ZA test proposed by Zivot and Andrews (1992), we tested the presence of cointegration by Gregory-Hansen (1996) cointegration methodology and find the appropriate cointegration vectors.

The present paper aims to examine the above-mentioned problem in Czech Republic, Hungary, Poland and Serbia; because these countries have many common features. One of the most valuable contributions of the current study is the testing, for the first time for some of these countries, the hypothesis of CA sustainability through the framework of cointegration between export and import. In addition, extended period of analysis allows a deeper insight into the consequences of recent global crisis. The main hypothesis of the research is that CA sustainability in Czech Republic, Hungary, Poland and Serbia is present when the possible structural breaks are incorporated in the analysis.

The paper is organized as follows. An overview of the research literature on this area is presented first. A theoretical approach to the problem, which is the basis for the empirical part of the work, is in the focus of the next section. Next, we briefly describe the methodology used in the research from an empirical aspect. After that, we provide basic information about the data used in the analysis and show the research results, with special emphasis on their economic interpretation. Finally, we discuss the results in the context of previous theoretical and empirical findings and give policy implications.

\section{Literature review}

In literature, there are, roughly speaking, two different frameworks for testing the sustainability of CA balance. One is the accounting approach, and the other is based on testing the intertemporal solvency. The first approach has its advantages; however, setting the objective and methodology of our study, we focused only on the second approach. Special attention was given to works that applied cointegration approach between export and import as the basis in their methodological set. What is worth mentioning is that it is the fiscal area that has developed available tools and 
methodological apparatus that has greatly contributed to testing the sustainability based on the intertemporal solvency. Therefore, we shall start by describing these contributions in fiscal area in brief.

One of the first studies that dealt with the cointegration of budget revenues and expenditures was carried by Trehan and Walsh (1988). They concluded that stationarity of the primary budget deficit is neither a necessary nor a sufficient condition. Hakkio and Rush (1991) also used the cointegration approach to investigate the problem of fiscal sustainability. They pointed to a potential issue regarding the possibility of marketing the debt. Quintos (1995) introduced the concept of weak sustainability. She stated that cointegration is only sufficient condition for budget sustainability, whereas the value of the parameter from the cointegration vector, which is between 0 and 1 , is necessary and sufficient condition.

The origins of this type of testing of CA sustainability can be found in Hakkio and Rush (1991) and Husted (1992). These papers have given the motivation for authors to apply their framework in order to investigate the sustainability of CA balance through the process of cointegration between export and import.

We will briefly present the research papers that deal with the CA sustainability, through the methodology of unit root testing or cointegration testing, since they are common techniques in the literature applied to this problem. Apergis et al. (2000) found evidence in favor of sustainability in the case of Greece for the period of 1969-1994. Liu and Taner (2001) for G7 countries found that majority of them violated CA constraint. Arize (2002) pointed out that 19 out of 50 observed countries did not comply with a solvency condition in the 1973-1998 period. Baharumshah et al. (2003) concluded that in Indonesia, Malaysia, the Philippines and Thailand the constraint is not satisfied for the period of 1961-1999. Holmes (2004) tests the stationarity and sustainability of CA deficits for ten transition economies. His results suggested that over half of the sample (the Czech Republic, Estonia, Hungary, Poland, Romania and the Slovak Republic), are characterized by CA sustainability where the impact of a CA shock on external debt will be shortrather than long- run. Chortareas et al. (2004) by employing the threshold unit root test found that in the observed countries the constraint is fulfilled. Dugler and Ozdemir (2005) pointed out that in France, Italy and Canada from G7 countries the constraint is hold, but not in other countries. Herzer and Nowak-Lehmann (2006) found that in Chile the CA balance is sustainable for the period 1975-2004. Onel and Utkulu (2006) stated that the constraint has weakly hold in Turkey from 1970 to 2002. Ismail and Baharumshah (2008) investigated the CA balance sustainability in Malaysia for the period of 1960-2004 and found that the sustainability hypothesis holds. Kim et al. (2009) applied non-linear unit root test and showed that sustainability holds for Indonesia, Korea, Malaysia, the Philippines and Thailand in the period 1981-2003. Konya (2008) investigates the sustainability problem for the Czech Republic, Hungary and Slovenia, with different length of samples and found 
that Slovenia violated the constraint, while the Czech Republic and Hungary did not. Ogus and Sohrabji (2008) did not find the evidence of sustainability in Turkey in the period 1992-2004. Brissimis et al. (2010) for the case of Greece found that Greece's external position was sustainable in the period from 1960 to 1998, but not in the later period from 1999 to 2007. Christopoulos and Leon-Ledesma (2010) found that US economy holds the constraint from 1960 to 2008. Chen (2011) found that sustainability cannot be confirmed for Australia, The Czech Republic, Finland, Hungary, New Zealand, Portugal and Spain. Binatli and Sohrabji (2012) found that Turkey remains vulnerable to reversals in capital flows. Murat et al. (2014) found the same as the previous study. Singh (2015) pointed out that India satisfied the constraint for the long length sample. Dugler (2016) presented the results which indicate that for all countries the stability tests reject the null of coefficient stability of the long-run relationship between exports and imports, and that cointegration tests imply weak form of sustainability. Cigdem (2017) found evidence obtained from LM unit root test with two structural breaks that CA deficits in Turkey are sustainable. Afonso et al. (2017) assesses the sustainability of the CA balance and external debt in a sample of EU countries and find that sustainability is not rejected for Austria, Belgium, Denmark, Estonia, and Germany and that there is concern about the sustainability of external debt in Latvia, Greece, Portugal, Romania, Estonia, and Lithuania. Iyidogan and Turan (2018) found that in Turkey, Poland and the Czech Republic CA deficit is not sustainable, whereas in Hungary the results are mixed.

In literature, papers that applied the proposed methodology on panel data can be found. $\mathrm{Wu}(2000)$ found that sustainability hypothesis holds for 10 OECD observed countries. Wu et al. (2001) found the same for G7 countries for the period 19731998. By employing panel unit root test, Lau and Baharumshah (2005) found that 3 out of 12 observed Asian countries hold the sustainability constraint. Lau et al. (2006) found for 5 Asian countries the evidence in favor of sustainability. Kalyoncu (2006) employed panel unit root test and found that in 22 OECD countries the CA balance is sustainable for the period 1960-2002. Holmes (2006) through the methodology of panel cointegration found that 5 of 11 OECD countries violated the constraint. Chu et al. (2007) found that 37 of 48 African countries satisfied the constraint.

In the separate table we will provide the information on the applied method of investigation of CA sustainability for the previously mentioned studies. This table will reveal the common econometric techniques used to analyze the problem, which will contribute to our decision on chosen methodology. 
Table 1: Summary of methodology of CA sustainability testing in the previous studies

\begin{tabular}{|c|c|c|}
\hline Author(s) & Country & Methodology \\
\hline Apergis et al. (2000) & Greece & cointegration analysis \\
\hline Liu and Taner (2001) & G7 countries & unit root test \\
\hline Arize (2002) & 50 countries & cointegration analysis \\
\hline Baharumshah et al. (2003) & $\begin{array}{l}\text { Indonesia, Malaysia, } \\
\text { Philippines, Thailand }\end{array}$ & $\begin{array}{l}\text { unit root test and cointegration } \\
\text { analysis }\end{array}$ \\
\hline Holmes (2004) & Ten transition economies & unit root tests \\
\hline Chortareas et al. (2004) & 12 Latin America countries & threshold unit root test \\
\hline Dugler and Ozdemir (2005) & G7 countries & unit root test \\
\hline $\begin{array}{l}\text { Herzer and Nowak-Lehmann } \\
(2006)\end{array}$ & Chile & $\begin{array}{l}\text { unit root test and cointegration } \\
\text { analysis }\end{array}$ \\
\hline Onel and Utkulu (2006) & Turkey & $\begin{array}{l}\text { unit root test and cointegration } \\
\text { analysis }\end{array}$ \\
\hline Ismail and Baharumshah (2008) & Malaysia & unit root test \\
\hline Kim et al. (2009) & $\begin{array}{l}\text { Indonesia, Korea, Malaysia, } \\
\text { Philippines, Thailand }\end{array}$ & non-linear unit root test \\
\hline Konya (2008) & $\begin{array}{l}\text { Czech Republic, Hungary, } \\
\text { Slovenia }\end{array}$ & $\begin{array}{l}\text { unit root test and cointegration } \\
\text { analysis }\end{array}$ \\
\hline Ogus and Sohrabji (2008) & Turkey & $\begin{array}{l}\text { unit root test and cointegration } \\
\text { analysis }\end{array}$ \\
\hline Brissimis et al. (2010) & Greece & cointegration analysis \\
\hline $\begin{array}{l}\text { Christopoulos and Leon- } \\
\text { Ledesma (2010) }\end{array}$ & US & STAR unit root test \\
\hline Chen (2011) & $\begin{array}{l}\text { Australia, Czech Republic, } \\
\text { Finland, Hungary, New } \\
\text { Zealand, Portugal, Spain }\end{array}$ & unit root tests \\
\hline Binatli and Sohrabji (2012) & Turkey & cointegration analysis \\
\hline Murat et al. (2014) & Turkey & cointegration analysis \\
\hline Singh (2015) & India & cointegration analysis \\
\hline Dugler (2016) & $\begin{array}{l}18 \text { developed and } 10 \\
\text { developing countries }\end{array}$ & cointegration analysis \\
\hline Cigdem (2017) & Turkey & unit root tests \\
\hline Afonso et al. (2017) & Sample of EU countries & $\begin{array}{l}\text { unit root test and cointegration } \\
\text { analysis }\end{array}$ \\
\hline Iyidogan and Turan (2018) & $\begin{array}{l}\text { Hungay, Poland, Czech } \\
\text { Republic, Turkey }\end{array}$ & $\begin{array}{l}\text { linear and non-linear unit root } \\
\text { test and cointegration analysis }\end{array}$ \\
\hline $\mathrm{Wu}(2000)$ & 10 OECD countries & panel unit root test \\
\hline Wu et al. (2001) & G7 countries & panel cointegration \\
\hline Lau and Baharumshah (2005) & 12 Asian countries & panel unit root test \\
\hline Lau et al. (2006) & 5 Asian countries & panel unit root test \\
\hline Kalyoncu (2006) & 22 OECD countries & panel unit root test \\
\hline Holmes (2006) & 11 OECD countries & panel cointegration \\
\hline Chu et al. (2007) & 48 African countries & SURADF panel unit root test \\
\hline
\end{tabular}


Our motivation for researching this area has two origins, which are related to methodological sphere and importance of the CA unsustainability issue. There is a lack of the research for the observed countries in our sample, and especially for our period of observation. We did not find any of this kind of research methodology applied on Serbia. Many papers analyzed the problem through the concept of unit root testing of CA balance. A few papers did that through the concept of cointegration. In addition, the possibility of structural breaks is often neglected. This is very important, because recent global crisis certainly has had an influence on CA sustainability and our sample encompasses this period. Finally, motivation emerges from the importance of analysis of repercussions that CA unsustainability can trigger. Aristovnik (2006, p. 87) pointed out that during the last three decades most financial crises highlighted the part played by large CA deficits in the run-up to crisis episodes. In addition, dependent on the state of the business cycle, the power of fiscal policy to influence CA balance can be substantially decreased, especially in periods of expansion, and therefore, one important tool for stabilization cannot be used (Grubišić et al., 2018, p. 330). Finally, the majority of the papers that deals with this topic are covering developed countries, or other countries, especially in Asia. All this opens the space to investigate the hypothesis of sustainability in these countries by employing the tools which are in step with the time.

\section{Methodology}

Econometric methodology which will be used in order to test the main hypothesis of the paper cannot be observed per se, without having in mind the theoretical basis of the problem. In that context, we will first briefly present intertemporal approach from the theoretical perspective, and then proceed to empirical side of the proposed methodology.

\subsection{Theoretical framework of the problem}

In the process of analyzing the problem from the theoretical aspect of view, we will follow methodology developed by Hakio and Rush (1991) and Husted (1992). In addition, we include government expenditures in the budget constraint equation. The intertemporal budget constraint can easily be deduced from an equation that represents the budget constraint in a given period, as shown in Eq. 1.

$$
C_{t}=Y_{t}+B_{t}-I_{t}-G_{t}-\left(1+r_{t}\right) * B_{t-1}
$$

Where $C, Y, B, I, G$ and $r$ are consumption, income, net borrowing, investment, government expenditures and interest rate, respectively. If we include $n$ periods into the model, where $n$ can converge to infinity, we can transform the equation into: 


$$
B_{t}=\sum_{i=1}^{\infty} \gamma_{i}\left(Y_{t+i}-C_{t+i} I_{t+i}-G_{t+i}\right)+\lim _{n \rightarrow \infty} \gamma_{n} * B_{t+n}
$$

In the previous equation, parameter $\gamma$ represents discount factor which has the folowing form:

$$
\gamma_{i}=\prod_{j=1}^{i} \frac{1}{1+r_{t+j}}
$$

The essence of fulfilling the intertemporal budget constraint is the absence of a Ponzi scheme. If the state acts in accordance with a Ponzi scheme, the debt due will always be replaced with a new debt. In theory, the absence of a Ponzi scheme implies that:

$$
\lim _{n \rightarrow \infty} \gamma_{n} * B_{t+n}=0
$$

In this case, the present value of all future CA balances will be equal to the current value of the net borrowing; i.e., subject to the transversality condition, the present value of net borrowing will converge to 0 in infinity. We can rearange the first equation in order to involve export $(X)$ and import $(M)$ in the folowing fashion:

$$
X_{t}-M_{t}=Y_{t}-C_{t}-I_{t}-G_{t}=-B_{t}+\left(1+r_{t}\right) * B_{t-1}
$$

If we assume stationarity of the world interest rate $r$, with mean $r$, we can derive the folowing equation:

$$
M_{t}+\left(r_{t}-r\right) * B_{t-1}+(1+r) * B_{t-1}=X_{t}+B_{t}
$$

Where modified import $(Q)$ is:

$$
Q=M_{t}+\left(r_{t}-r\right) * B_{t-1}
$$

Finally, iterating forward we can get this expression:

$$
Q_{t}=X_{t}+\sum_{j=0}^{\infty} \gamma^{j-1}\left(\Delta X_{t+j}-\Delta Q_{t+j}\right)+\lim _{t \rightarrow \infty} \gamma^{t+j} * B_{t+j}
$$

Where discount factor is:

$$
\gamma=\frac{1}{1+r}
$$

Hereafter, we will use the term import for modified import variable named $Q$. 


\subsection{Empirical prism of methodology}

Testing the existence of CA balance sustainability can be done in many ways, as reported in economic literature. We decided to use the methodology of cointegration between export and import. The empirical testing of intertemporal CA solvency starts with the equation no. 8. Suppose that the last part of the expression tends to 0 and that export and import are series with one unit root, then their first differences result in stationary time series. In this case, the fulfillment of the intertemporal CA solvency requires the presence of cointegration between $X$ and $Q$. If the export and import time-series are integrated of order 0 , then this is a sufficient condition of sustainability. If both series are I(1), the sustainability thesis can be confirmed or rejected through the cointegration concept. If one series is $\mathrm{I}(0)$ and the other is $\mathrm{I}(1)$, then unsustainability is proven.

If we do not mind of the presence of the eventual structural breaks, the observed cointegration equation has the following form:

$$
\text { Export }=\alpha+\beta * \text { Import }+e_{t}
$$

For developing countries with persistent CA deficits, a case of weak sustainability is especially relevant. If the coefficient $\beta$ in the cointegration vector $[1,-\beta]$ is less than 1 , then there is no strong sustainability, but rather weak sustainability. Hakkio and Rush (1991) showed that even when the cointegration vector is not $[1,-1]$, the intertemporal constraint can be fulfilled. However, country can have difficulties in servicing foreign debt.

We thought that above presented methodology has to be improved and that tools used for conclusions making have to be in step with the time. During last two decades, many improvements of the established tools, but also new ones have been created. This is our main contribution, because we think that results now are more reliable.

To obtain reliable conclusions, before we proceed to testing of the cointegration, we firstly perform three types of unit root tests: Augmented Dickey-Fuller (ADF) test, Kwiatkowski-Phillips-Schmidt-Shin (KPSS) test and Zivot-Andrews (ZA) test. The first two tests are the most common in the literature. The ADF test starts with the null hypothesis that there is at least one unit root in a series. In the event of nonrejection of the null hypothesis, the testing is continued to examine in an analogous manner the presence of a unit root in the first difference series. We use Schwarz Information Criterion for determination of optimal lag length. To strengthen the reliability of the results, the analysis also employs the KPSS test, according to which the null hypothesis asserts that there is no unit root in the time series. We assumed a linear decline of correlation over time, i.e. the Bartlett kernel is used. Because the above-mentioned unit root tests are extremely sensitive to the existence of deterministic components in the time series movement, we have to identify 
which deterministic components should be used in the analysis. This is done based on the visual examination and the Stock-Watson test with Newey-West correction. The rejection of the null hypothesis in this test justifies the inclusion of the constant and trend as deterministic components when testing series for unit root presence. Otherwise, the trend should be excluded from the model and this algorithm has to be repeated by using only constant as deterministic component. Finally, we used ZA test, because it accounts for the presence of structural break in the movement of the series, which is endogenously determined. The theoretical and empirical literature has shown that the errors in conclusions made only by standard unit roots tests can be significant. The common belief is to start with the most comprehensive modality of the test and based on the visual observation to decide what modality is the most appropriate to the observed time-series. For quarterly data the common lag length used is 4 .

The existence of cointegration between the two series previously mentioned was tested by the Gregory-Hansen test of cointegration. It accounts for possible presence of structural break as opposed to standard frameworks of cointegration testing. The null hypothesis of non-cointegration is tested against the alternative of cointegration in the presence of a possible single shift of unknown timing. We perform analysis of several forms of structural change in the parameters of the cointegrating vector: the level shift model $(\mathrm{C})$, the level shift with trend model $(\mathrm{C} / \mathrm{T})$ and the regime shift model $(\mathrm{C} / \mathrm{S})$, but in final draft we used only the last two modalities. We opted for $\mathrm{C} / \mathrm{T}$ and $\mathrm{C} / \mathrm{S}$ since the results and structural breaks which are compatible with ZA test and visual examination of the series routed us toward that direction. We use Schwarz Information Criterion for determination of optimal lag length. The models $\mathrm{C} / \mathrm{T}$ and $\mathrm{C} / \mathrm{S}$ are defined as follows, respectively:

$$
\begin{aligned}
& \text { Export }=\varphi_{1}+\varphi_{2}{ }^{*} \text { Dummy }_{t}(\tau)+\varphi_{3}{ }^{*} \text { Trend }+\beta * \text { Import }+e_{t} \\
& \text { Export }=\varphi_{1}+\varphi_{2}{ }^{*} \text { Dummy }_{t}(\tau)+\beta * \operatorname{Import}+\varphi_{3} * \operatorname{Import} * \operatorname{Dummy}_{t}(\tau)+e_{t}
\end{aligned}
$$

In the first equation, $\varphi_{1}, \varphi_{2}, \varphi_{3}, \beta, \mathrm{e}_{\mathrm{t}}$ correspond to intercept before change, corresponding change in intercept after the break, trend coefficient, slope and standard error, respectively. Dummy variable takes value of 0 if $t \leq \tau$ and 1 if $t>\tau$. In the second equation, $\varphi_{1}, \varphi_{2}, \beta, \varphi_{3}$, $\mathrm{e}_{\mathrm{t}}$ correspond to intercept before change, corresponding change in intercept after the break, slope, corresponding change in the slope after the break and standard error, respectively. Dummy variable, again takes value of 0 if $t \leq \tau$ and 1 if $t>\tau$. We computed the ADF test statistic and the Phillips (1987) test statistics, $\mathrm{Z}_{\mathrm{a}}$ and $\mathrm{Z}_{\mathrm{t}}$, for each possible break point $\tau$ in the interval ([0.15T], [0.85T]). In the case of the cointegration presence, we estimated cointegration equation consistent with the employed Gregory-Hansen test modality in order to observe the value of $\beta$ coefficient, which is of special interest to us. 


\section{Empirical data and analysis}

We decided to analyze the problem in four countries. Three of them are countries from the Central Europe, members of the European Union, and one is Serbia, from the South-East Europe, a candidate country for EU accession. We include these countries into analysis, because they have many features in common.

First and the most important common characteristic is flexible exchange rate. The observed countries as inflation targets do not have explicit exchange rate goal, but certainly could indirectly have the influence on the CA balance by this mechanism. Kovačević (2017) found that real effective exchange rate appreciation has an adverse effect on CA. Recent global financial crisis has shown that countries that have the flexibility of adjustments based on the exchange rate were in better position than others which do not have that instrument in their controllable set. The trends in CA balances in these countries clearly support the thesis of better absorption of the shocks that hit the economy in the case of flexible exchange rate, because this mechanism gives the flexibility and maneuver space to policymakers in the case of crisis.

Besides that, all of the observed countries are small open economies that are vulnerable to external shocks. They have had persistent CA deficits in the past and were experiencing sudden capital movements. Their fragility has its roots in the openness and liberalization.

The observed countries were part of central-planning economies block in the past. This has a consequence that all of them had to make structural changes during the transition process.

Finally, they are all inflation targets. According to Rose (2007), inflation targeting cannot significantly influence CA sustainability, because this system was not planned and does not rely on international coordination. However, this monetary regime implies flexible exchange rate and focus of policymakers on the other macroeconomic objectives in the domestic sphere, which can sometimes be in conflict with CA sustainability. Besides this, Serbia has to make progress in many areas, and these countries are good benchmark in that process. Therefore, abovementioned reasons and many common structural characteristics of these countries have routed us to choose them in our sample for analysis.

\subsection{Data}

The necessary raw data were extracted from the balance of payments of the Czech Republic, Hungary, Poland and Serbia and were taken from the Eurostat database. The literature cites various modalities regarding the type of data used in the analysis. In the case of the observed countries, we believe that the data normalized to GDP provide the best basis for analysis. 
An important notice has to be emphasized regarding the definition of the variables. As explained and used in Binatli and Sohrabji (2012) and Apergis, et al. (2000) the variable import has to be modified. The reason for this modification in the empirical specification can be found in the theoretical part of the paper. In empirical literature this is done by correction of original import series. Namely, variable import is corrected for net factor incomes (NFI) and net unilateral transfers (NUT), according to the formula adopted in the above-mentioned literature, which states that $Q=$ $M+N F I+N U T$. Consequences of this kind of modification can be seen in the Appendix.

We observed the time series on a quarterly basis. The samples for the observed countries are of the same length, from $2007 \mathrm{q} 1$ to $2017 \mathrm{q} 4$, which in total are 44 observations. Because the observed time series showed distinctive seasonal variations, we de-seasonalized the data by using the CENSUS X12 method, with multiplicative component. Hereafter, for the purpose of simplification, we will use the terms export and import without the attributes "de-seasonalized"or "modified". The time-series for the all observed countries of the variables which are used in the analysis can be seen in figures in the Appendix. After this transformation, the foundations for further empirical analysis were set.

\subsection{Empirical results}

The precondition for the cointegration analysis is to determine the integration of the observed time series. The results of the unit root testing showed that the majority of the tests indicate that the export and import series are integrated of order 1 . On the other hand, the employed tests on the time series of balances showed that in the majority of cases the series are stationary, especially when the ZA test is employed. That can indicate the CA balance is sustainable when we account for structural breaks. As explained in the chapter dedicated to the methodology, ZA test has advantages over ADF and KPSS test, since it includes the possibility of the structural breaks. Also, in empirical literature, there is a common stance to begin with the most comprehensive version of the ZA test. However, there is always the possibility of the errors, especially when the time series does not have enough length. Therefore, we accepted these results (More details on unit root testing results can be found in the Appendix) with caution and proceeded to testing of cointegration presence between export and import. 
Miomir Jakšić, Nikola Fabris, Milutin Ješić • Intertemporal current account...

Table 2: Summary of unit root testing ( $\alpha=5 \%)$

\begin{tabular}{|c|c|c|c|c|c|c|}
\hline & & $\mathrm{ADF}$ & KPSS & ZA: Type A & ZA: Type B & ZA: Type C \\
\hline \multirow{3}{*}{ Czech R. } & Export & $\mathrm{I}(1)$ & $\mathrm{I}(1)$ & $\mathrm{I}(1)$ & $\mathrm{I}(1)$ & $\mathrm{I}(1)$ \\
\hline & Import & $\mathrm{I}(1)$ & $\mathrm{I}(1)$ & $\mathrm{I}(1)$ & $\mathrm{I}(1)$ & $\mathrm{I}(1)$ \\
\hline & Balance & $\mathrm{I}(0)$ & $\mathrm{I}(0)$ & $\mathrm{I}(0)$ & $\mathrm{I}(0)$ & $\mathrm{I}(0)$ \\
\hline \multirow{3}{*}{ Hungary } & Export & $\mathrm{I}(1)$ & $\mathrm{I}(1)$ & $\mathrm{I}(1)$ & $\mathrm{I}(1)$ & $\mathrm{I}(1)$ \\
\hline & Import & $\mathrm{I}(1)$ & $\mathrm{I}(1)$ & $\mathrm{I}(1)$ & $\mathrm{I}(1)$ & $\mathrm{I}(1)$ \\
\hline & Balance & $\mathrm{I}(1)$ & $\mathrm{I}(1)$ & $\mathrm{I}(0)$ & $\mathrm{I}(1)$ & $\mathrm{I}(0)$ \\
\hline \multirow{3}{*}{ Poland } & Export & $\mathrm{I}(1)$ & $\mathrm{I}(1)$ & $\mathrm{I}(1)$ & $\mathrm{I}(0)$ & $\mathrm{I}(0)$ \\
\hline & Import & $\mathrm{I}(1)$ & $\mathrm{I}(1)$ & $\mathrm{I}(1)$ & $\mathrm{I}(1)$ & $\mathrm{I}(1)$ \\
\hline & Balance & $\mathrm{I}(0)$ & $\mathrm{I}(0)$ & $\mathrm{I}(0)$ & $\mathrm{I}(0)$ & $\mathrm{I}(0)$ \\
\hline & & & & & & \\
\hline \multirow{3}{*}{ Serbia } & Export & $\mathrm{I}(1)$ & $\mathrm{I}(1)$ & $\mathrm{I}(1)$ & $\mathrm{I}(1)$ & $\mathrm{I}(1)$ \\
\hline & Import & $\mathrm{I}(1)$ & $\mathrm{I}(1)$ & $\mathrm{I}(0)$ & $\mathrm{I}(1)$ & $\mathrm{I}(0)$ \\
\hline & Balance & $\mathrm{I}(1)$ & $\mathrm{I}(1)$ & $\mathrm{I}(0)$ & $\mathrm{I}(1)$ & $\mathrm{I}(0)$ \\
\hline
\end{tabular}

Source: Authors' calculations

After determination of the integration level of the export and import series, all the required preconditions for the cointegration test are obtained. Since we accept the hypothesis that the export and import series are I(1) in all countries, there is a possibility that their linear combination is $\mathrm{I}(0)$. In order to investigate this thesis, we employed Gregory-Hansen cointegration methodology, since it accounts for the presence of the structural breaks.

Table 3: Gregory-Hansen cointegration test results

\begin{tabular}{|l|c|c|c|c|c|c|c|}
\hline \multicolumn{4}{|c|}{ ADF procedure } & \multicolumn{4}{c|}{ Phillips procedure } \\
\hline Country & Model & t statistic & $\begin{array}{c}\text { Break } \\
\text { date }\end{array}$ & $\mathrm{Z}_{\mathrm{a}}$ statistic & $\begin{array}{c}\text { Break } \\
\text { date }\end{array}$ & $\mathrm{Z}_{\mathrm{t}}$ statistic & $\begin{array}{c}\text { Break } \\
\text { date }\end{array}$ \\
\hline Czech R. & $\mathrm{C} / \mathrm{S}$ & $-6.60^{*}$ & $2013 \mathrm{Q} 2$ & $-45.06^{* * *}$ & $2013 \mathrm{Q} 2$ & $-6.68^{*}$ & $2013 \mathrm{Q} 2$ \\
\hline Hungary & $\mathrm{C} / \mathrm{T}$ & $-5.28^{* *}$ & $2010 \mathrm{Q} 2$ & -33.97 & $2010 \mathrm{Q} 2$ & $-5.35^{* *}$ & $2010 \mathrm{Q} 2$ \\
\hline Poland & $\mathrm{C} / \mathrm{T}$ & $-6.25^{*}$ & $2008 \mathrm{Q} 2$ & -42.00 & $2008 \mathrm{Q} 2$ & $-6.33^{*}$ & $2008 \mathrm{Q} 2$ \\
\hline Serbia & $\mathrm{C} / \mathrm{S}$ & $-5.11^{* *}$ & $2010 \mathrm{Q} 2$ & -34.08 & $2010 \mathrm{Q} 2$ & $-5.17^{* *}$ & $2010 \mathrm{Q} 2$ \\
\hline
\end{tabular}

Notes: $* * *$ and $* * *$ Denote significance at $1 \%, 5 \%$ and $10 \%$, respectively.

$\mathrm{C} / \mathrm{T}$ stands for Level shift with trend in Gregory and Hansen context

C/S stands for Regime shift in Gregory and Hansen context

Source: Authors' calculations 
The choice of the model in Gregory-Hansen cointegration test is made based on the visual observation of the series and on the information on break dates, in order to sustain the complementarities with the ZA unit root test. Besides this, all modalities of the Gregory-Hansen test showed the similar results, so the conclusions are robust to modalities variations. The overall results strongly support the evidence that there is a cointegration between the export and import with structural break in slope and intercept (regime shift) or only in the intercept when series have a deterministic trend in all of the observed countries. Only $Z_{\mathrm{a}}$ statistic showed different results in few countries, but the more common in literature is to use ADF procedure.

Based on the above results, we are able to estimate the cointegration equations in order to determine the value of the coefficient $\beta$, which is crucial for differentiation between the sustainability and unsustainability of CA balance. Having in mind the employed modality of Gregory-Hansen cointegration test, we estimated these cointegration equations.

$$
\begin{aligned}
\text { Export }_{C Z}= & 3.9410+22.5615^{*} \text { Dummy }_{C Z}+0.9060 * \text { Import }_{C Z} \\
& -0.2282 * \text { Import }_{C Z} * \text { Dummy }_{C Z} \\
\text { Export }_{H U}= & 31.5679+5.0280 * \text { Dummy }_{H U}+0.1862 * \text { Trend }_{H U}+ \\
& +0.5417 \text { Import }_{H U} \\
\text { Export }_{P L}= & 20.8711-2.5931 * \text { Dummy }_{P L}+0.3728 * \text { Trend }_{P L}+ \\
& +0.3783 * \text { Import }_{P L} \\
\text { Export }_{S R B}= & 23.0395-39.6884 * \text { Dummy }_{S R B}+0.1057 * \text { Import }_{S R B} \\
& +1.0915 * \text { Import }_{S R B}{ }^{*} \text { Dummy }_{S R B}
\end{aligned}
$$

Dummy $_{C Z}$ takes a value 0 for the quarters [2007q1-2013q1] and 1 for the quarters [2013q2-2017q4]. Dummy ${ }_{H U}$ takes a value 0 for the quarters [2007q1-2010q1] and 1 for the quarters [2010q2-2017q4]. Dummy $P_{P L}$ takes a value 0 for the quarters [2007q1-2008q1] and 1 for the quarters [2008q2-2017q4]. Dummy $y_{S R B}$ takes a value 0 for the quarters [2007q1-2010q1] and 1 for the quarters [2010q2-2017q4].

\subsection{Interpretation of the empirical results}

A few results have to be mentioned. The majority of the observed series are likely to be non-stationary. This result makes it possible to examine the possibility of cointegration presence. The results of the cointegration test and estimated cointegration equation clearly showed one stationary linear combination of export and import in all of the observed countries, which support the conclusion 
of CA sustainability to some extent. Export and import series construct long-term equilibrium relationship. This means that in the broad sense CA sustainability is fulfilled in the context of intertemporal approach. This is first conclusion of our analysis.

The above-presented result gives us a maneuver space for the estimation of cointegration equations. We estimated the equations having in mind the high probability of structural changes presence, which was proved by Gregory-Hansen methodology. We find the best suitable modality of the test and also cointegration equation form with the purpose of precisely estimation of the cointegration vectors. We were especially interested in the value of parameter $\beta$.

The results relating to the parameter $\beta$ strongly differentiate these countries, besides the proven intertemporal sustainability of CA balance. In Czech Republic and to some extent in Hungary, the estimated coefficient contributes to the conclusion of stronger sustainability. On the other side, in the cases of Poland and Serbia, these results show weak sustainability with potential explosion of external debt. We can conclude that debt of these countries is not bounded and that it is vulnerable to many possible shocks. Results are to some extent consistent with the unit root testing in the series of CA balance.

\section{Results and discussion}

The overall results that CA sustainability is not rejected for these countries are expected. This result implicitly contributes to the positive sides of exchange rate flexibility. It has its advantages and disadvantages. However, related to the CA balance, exchange rate flexibility allows for economy adjustments in the periods of crisis.

Since our period of observation includes the period of global economic crisis and shocks that hit the economies were substantial, we expected inherence of structural breaks. This has been confirmed by results of the tests that account for that possibility. Especially important is the conclusion that there is a cointegration between export and import, but that these long-run relationships between the observed variables are established in presence of structural breaks. This is robust result since the unit root testing of CA balance which account for structural breaks contributes to the same conclusion. This is consistent with economic theory as well as most empirical economics contributions.

It is useful to make a comparison of the results with other studies related to these countries, irrespectively of the underline methodology. Our study is, up to our knowledge, first that deals with the problem of CA sustainability in similar fashion in some countries in the sample. Other countries' balances were analyzed in 
different period or by different methodology. It is important to analyze the problem after the global crisis finished. Our results are consistent with the work of Holmes (2004), who has shown that Czech Republic, Hungary and Poland, among other analyzed countries, are characterized by CA sustainability. Also, it is consistent with Konya (2008) results, where author found that Czech Republic and Hungary did not violate the constraint. On the other side, Chen (2011) found that sustainability cannot be confirmed for the Czech Republic and Hungary among other observed countries for the period of 1991Q1 to 2009Q3 for Czech Republic and 1993Q1-2009Q3 for Hungary. Apart from previous findings consistency, we make the analysis more reliable by using the most relevant tests that account for structural shifts. Extended period of research and incorporation of consequences of global crisis give to our conclusions characteristics such as relevance, robustness and accuracy.

All the above mentioned has routed us to the policy implications. As we already pointed out, testing the intertemporal sustainability of CA balance is only one approach to the problem of the overall sustainability which emphasizes macroeconomic context. We are inclined to think that this is only necessary, not sufficient condition which has to be met. The vulnerability of these countries to external shocks, currency crises, and fiscal irresponsibility is high, and therefore they have to identify, observe and resolve all issues related to the solvency of external position. We also have to mention that other macroeconomic variables can trigger the stance of the CA. Therefore, special attention has to be dedicated to these kinds of shocks during the process of policymaking. Fiscal balance has impact on CA. This postulate has been proved by the Mundell-Fleming model and hypothesis of twin-deficits. On the other side, we want to emphasize the reversible nature of the relationship between CA sustainability and macroeconomic stability. Instability in CA has adverse effects on macroeconomic stability through the exchange rate spillovers, capital flight, currency crises, fiscal instability etc.

Growing CA deficits are not concerning when country has stable resources for funding these misbalances. However, many developing countries are dependent of some structurally instable forms of deficit financing. Second problem is deficit persistency which is obvious in some of the observed countries. These issues call for special monitoring and precautionary measures in the case of CA unsustainability. Our study revealed that all of the observed countries have to make structural changes in order to improve its position. However, these improvements will be observable in the long-run. When discuss implications of potential CA unsustainability, we have to keep in mind that EU countries are under the special monitoring of European Commission based on Macroeconomic Imbalance Procedure introduced in 2011. It is designed to prevent (preventive arm) and correct (corrective arm) risky macroeconomic developments, which encompass the current account unsustainability. This procedure comprises sequential phases including Alert Mechanism Report based on a scoreboard of indicators, In-Depth Reviews 
and Excessive Imbalance Procedure. Serbia, as candidate country is not monitored under that mechanism. Therefore, we will briefly explain key factors of Serbia's CA sustainability.

High and persistent CA deficits in Serbia in the past are consequence of many factors that have had one-off or structural dimension. Structural negative gap between the export and import can be explained by adoption of the country development model. Policy of real appreciation and growth based on the high demand has triggered many consequences, especially before the global economic crisis. Competitiveness and export orientation of the Sebian economy have been low fo the long period of time. Structural policies have not been oriented toward improvement in this area. Serbia has financed high and persistent CA deficits by foreign borrowing, and therefore closed the gap between investment and savings. The decrease in interest rates on international markets makes it possible to get loans under favorable conditions, which increases the level of debt. However, the rise in debt has not been followed by increase in capability to service the debt obligations. After the crisis, many countries have experienced decrease in CA deficits because of stagnancy in economic activity and structural adjustments. The primary income is constantly in deficit. It is consequence of inadequate concept of development after the transition period. Secondary income is in high surplus, because of remittances that are among the highest in Europe. This is the main factor contributing to CA sustainability (see Appendix). These consequences call for policy reaction that has to include measures that decrease the expenditures, that rebalance expenditures and structural measures. They should stimulate the competitiveness of the goods and services on the international markets. According to Iyidogan and Turan (2018), more saving friendly policies would be helpful in addressing this structural problem.

The EU membership certainly improves the position of other observed countries, but they also have to make substantial progress in order to be in a step with developed countries. These measures that have to be implemented are not isolated from other macroeconomic objectives. According to this, the problem of CA sustainability has to be observed in a broader context.

\section{Conclusion}

The external position of many countries requires a deep analysis and review of the CA balance determinants. In this research we wanted to focus on the macroeconomic side of the problem. We tried to examine the long-term sustainability. In theory, fulfillment of the constraint requires that No-Ponzi condition has to be met. However, modifications have to be made in order to empirically test the solvency condition. We did that through the framework of cointegration between export and import. In addition, we put special attention on the possibility of presence of 
structural breaks, and therefore use tests that endogenously determine eventual breaks. Finally, we estimated cointegration equation and cointegration vectors. For the Czech Republic, Hungary, Poland and Serbia these vectors are [1,-0.9060], [1,0.5417], $[1,-0.3783]$ and $[1,-0.1057]$, respectively. We can conclude that constraint is fulfilled, but weak sustainability is inherent to Poland and Serbia. In general, our main hypothesis cannot be rejected. Our paper has extended the contribution of previous papers and has given useful insights into policymakers in the observed countries in macroeconomic perspective of CA sustainability. Main constraint of this research study is that data are not sufficiently long as it is in the developed countries. Therefore, we have to use quarterly data in order to estimate long-run relationship between the observed series. Besides that, there are only few papers that analyze the sustainability in these countries. But the results are not directly comparable. However, this study can be useful benchmark for any other which deals with similar kind of problems. It can be a backbone for future research, where accounting approach can be employed. Finally, it will be a useful part of broader research studies that analyze complete macroeconomic system. The macroeconomic consequences of these conclusions are numerous and valid for all observed countries. Uncertainty can easily empower small economic shocks into large ones that can affect macroeconomic stability. Therefore, institutional implications can be significant. It is necessary to implement structural reforms, with the purpose of economic strengthening. Policymakers now have precise diagnosis of the problem from the macroeconomic aspect of view.

\section{References}

Afonso, A. et al. (2017) "Assessing the Current Account Sustainability in the European Union”, Available at: <https://gdrnanterre2017.sciencesconf. org/143699/document>.

Apergis, N., Katrakilidis, K.P., Tabakis, N.M. (2000) "Current Account Deficit Sustainability: The Case of Greece", Applied Economics Letters, Vol. 7, No. 9, pp. 599-603, doi: 10.1080/13504850050059087.

Aristovnik, A. (2006) "Current account deficit sustainability in selected transition economies", Zbornik radova Ekonomskog fakulteta u Rijeci, časopis za ekonomsku teoriju i praksu /Proceedings of Rijeka Faculty of Economics, Journal of Economics and Business, Vol. 24, No. 1, pp. 81-102.

Arize, A.C. (2002) "Imports and exports in 50 countries: tests of cointegration and structural breaks", International Review of Economics and Finance, Vol. 11, No. 1, pp. 101-115, doi: 10.1016/S1059-0560(01)00101-0.

Baharumshah, A.Z., Lau, E., Fountas, S. (2003) "On the Sustainability of Current Account Deficits: Evidence from Four ASEAN Countries", Journal of Asian Economics, Vol. 14, No. 3, pp. 465-487, doi: 10.1016/S1049-0078(03)00038-1. 
Binatli, A.O., Sohrabji, N. (2012) "Intertemporal Solvency of Turkey's Current Account", Panoeconomicus, Vol. 59, No. 1, pp. 89-104, doi: 10.2298/ PAN1201089B.

Boronenko, V., Drezgić, S. (2014) "Economic Determinants of Territory Competitiveness and Development Sustainability", Social Sciences Bulletin / Socialo Zinatnu Vestnesis, No. 19, pp. 44-67.

Brissimis, S.N. et al. (2010) "Current Account Determinants and External Sustainability in Periods of Structural Change" ECB Working Paper, No. 1243, Available at: $<$ http://www.ecb.europa.eu/pub/pdf/scpwps/ecbwp1243.pdf $>$

Chen, S.W. (2011) "Current Account Deficits and Sustainability: Evidence from the OECD Countries", Economic Modelling, Vol. 28, No. 4, pp. 1455-1464, doi: 10.1016/j.econmod.2011.01.011.

Chortareas, G.E., Kapetanios, G., Uctum, M. (2004) "An Investigation of Current Account Solvency in Latin American Using Nonlinear Non-Stationarity Tests", Studies in Nonlinear Dynamics and Econometrics, Vol. 8, No. 1, pp. 1-17.

Christopoulos, D.K., León-Ledesma, M. (2010) "Current-Account Sustainability in the US: What do we Really Know about it?", Journal of International Money and Finance, Vol. 29, No. 3, pp. 442-459, doi: 10.1016/j.jimonfin.2009.06.014.

Chu, H.-P. et al. (2007) "Mean Reversion in the Current Account of Forty-eight African Countries: Evidence from the Panel SURADF Test", Physica A, Vol. 384, No. 2, pp. 485-492, doi: 10.1016/j.physa.2007.05.051

Cigdem, G. (2017) "Sustainability of Current Account Deficit in Turkey and an Empirical Analysis for Unit Root Test with Two Structural Breaks", International Journal of Economics and Finance, Vol. 9, No. 12, pp. 253-260, doi: 10.5539/ijef.v9n12p253.

Dulger, F., Ozdemir, Z.A. (2005) "Current Account Sustainability in Seven Developed Countries", Journal of Economic and Social Research, Vol. 7, No. 2, pp. 47-80.

Dulger F. (2016) "The Sustainability of Current Account in the Presence of Endogenous Multiple Structural Breaks: Evidence from Developed and Developing Countries", Panoeconomicus, Vol. 65, No. 4, pp. 339-358, doi: 10.2298/PAN1603339D .

Eurostat $<$ http://ec.europa.eu/eurostat $>$ [Accessed: July 25, 2018]

Gregory, A.W., Hansen, B.E. (1996a) "Residual-Based Tests for Cointegration in Models with Regime Shifts", Journal of Econometrics, Vol. 70, No. 1, pp. 99 126, doi: 10.1016/0304-4076(69)41685-7.

------- (1996b) "Tests for Cointegration in Models with Regime and Trend Shifts", Oxford Bulletin of Economics and Statistics, Vol. 58, No. 3, pp. 555-559.

Grubišić, Z., Kamenković, S., Zdravković, A. (2018) "Impact of Government Balance and Exchange Rate Regime on Current Account during the Economic 
Cycle: Evidence from CEE Countries", Zbornik radova Ekonomskog fakulteta u Rijeci, časopis za ekonomsku teoriju i praksu/Proceedings of Rijeka Faculty of Economics, Journal of Economics and Business, Vol. 36, No. 1, pp. 309-336, doi: 10.18045/zbefri.2018.1.309.

Hakkio, S.C., Rush, M. (1991) "Is the Budget Deficit "too large"?", Economic Inquiry, Vol. 29, No. 3, pp. 429-445, doi: 10.1111/j.1465-7295.1991.tb00837.x.

Herzer, D., Nowak-Lehmann, F. (2006) "Is there a Long-run Relationship between Exports and Imports in Chile?", Applied Economics Letters, Vol. 13, No. 15, pp. 981-986, doi: 10.1080/13504850500425832.

Holmes, M.J. (2004) "Current Account Deficits in the Transition Economies", Prague Economic Papers, Vol. 13, No. 4, pp. 243-267, doi: 10.18267/j.pep.247.

Holmes, M.J. (2006) "How Sustainable are OECD Current Account Balances in the Long-run?", Manchester School, Vol. 74, No. 5, pp. 626-643, doi: 10.1111/ j.1467-9957.2006.00514.x.

Husted, S. (1992) "The Emerging U.S. Current Account Deficit in the 1980s: A Cointegration Analysis", The Review of Economics and Statistics, Vol. 74, No. 1, pp. 159-166, doi: 10.2307/2109554.

Ismail, H.B., Baharumshah, A.Z. (2008) "Malaysia's Current Account Deficits: An Intertemporal Optimization Perspective", Empirical Economics, Vol. 35, No. 3, pp. 569-590, doi: 10.1007/s00181-007-0179-5.

Iyidogan, P.V., Turan, T. (2018) "Current Account Sustainability: A Non-Linear Comparative Empirical Overview”, Panoeconomicus, Vol. 65, No. 4, pp. 411426, doi: 10.2298/PAN141102007I .

Kalyoncu, H. (2006) "International Intertemporal Solvency in OECD Countries: Evidence from Panel Unit Root", Prague Economic Papers, Vol. 15, No. 1, pp. 44-49, doi: 10.18267/j.pep.275.

Kim, B., Min, H.-G., McDonald, J.A. (2009) "Are Asian Countries Current Accounts Sustainable? Deficits, even when Associated with High Investment, are not Costless", Journal of Policy Modeling, Vol. 31, No. 2, pp. 163-179, doi: 10.1016/j.jpolmod.2008.08.001.

Konya, L. (2008) "The Sustainability of the Current Account in the Czech Republic, Hungary and Slovenia", Empirical Economics, Vol. 36, No. 2, pp. 367-384, doi: 10.1007/s00181-008-0199-9.

Kovačević, R. (2017) "Current Account Determinants in Southeast European (SEE) Countries - Panel Approach", Zbornik radova Ekonomskog fakulteta u Rijeci, časopis za ekonomsku teoriju i praksu /Proceedings of Rijeka Faculty of Economics, Journal of Economics and Business, Vol. 35, No. 2, pp. 391-424, doi: 10.18045/zbefri.2017.2.391.

Kwiatkowski, D. et al. (1992) "Testing the Null Hypothesis of Stationarity against the Alternative of a Unit Root", Journal of Econometrics, Vol. 54, No. 1-3, pp. 159-178, doi: 10.1016/0304-4076(92)90104-Y. 
Lau, E., Baharumshah, A.Z. (2005) "Mean-Reverting Behavior of Current Account in Asian Countries", Economics Letters, Vol. 87, No. 3, pp. 367-371, doi: 10.1016/j.econlet.2005.01.006.

Lau, E., Baharumshah, A.Z., Haw, C.T. (2006) "Current Account: Mean-Reverting or Random Walk Behavior?", Japan and the World Economy, Vol. 18, No. 1, pp. 90-107, doi: 10.1016/j.japwor.2004.05.005.

Liu, P.C., Tanner, E. (2001) "International Intertemporal Solvency in Industrialized Countries: Evidence and Implications", Southern Economic Journal, Vol. 62, No. 3, pp. 739-749.

MacKinnon, J. (1991) "Critical Values for Cointegration Tests". In Engle, R.F., Granger, C.W.J. Eds., Long Run Economic Relationship: Readings in Cointegration, Oxford: Oxford University Press, pp. 267-276.

Murat, S., Hobikoglu, E.H., Dalyanci, L. (2014) "Structure and Sustainability of Current Account Deficit in Turkish Economy", Procedia - Social and Behavioral Sciences, Vol. 150, pp. 977-984, doi: 10.1016/j.sbspro.2014.09.110.

Ogus, A., Sohrabji, N. (2008) “On the Optimality and Sustainability of Turkey's Current Account", Empirical Economics, Vol. 35, No. 3, pp. 543-568, doi: 10.1007/s00181-007-0178-6.

Onel, G., Utkulu, U. (2006) "Modeling the Long-run Sustainability of Turkish External Debt with Structural Changes", Economic Modelling, Vol. 23, No. 4, pp. 669-682, doi: 10.1016/j.econmod.2006.03.006.

Quintos, E.C. (1995) "Sustainability of Deficit Process with Structural Shifts", Journal of Business and Economic Statistics, Vol. 13, No. 4, pp. 409-417.

Rose, A.K. (2007) "A Stable International Monetary System Emerges: Inflation Targeting is Bretton Woods, Reversed", Journal of International Money and Finance, Vol. 26, No. 5, pp. 663-681, doi: 10.1016/j.jimonfin.2007.04.004.

Singh, T. (2015) "Sustainability of Current Account Deficits in India: An Intertemporal Perspective", Applied Economics, Vol. 47, No. 46, pp. 4934 4951, doi: 10.1080/00036846.2015.1039701.

Trehan, B., Walsh, C. (1988) "Common Trends, the Government's Budget Constraint, and Revenue Smoothing", Journal of Economic Dynamics and Control, Vol. 12, No. 2-3, pp. 425-444, doi: 10.1016/0165-1889(88)90048-6.

Wu, J.-L. (2000) "Mean Reversion of the Current Account: Evidence from the Panel Data Unit-root test", Economics Letters, Vol. 66, No. 2, pp. 215-222, doi: 10.1016/S0165-1765(99)00198-6.

Wu, J.-L., Chen, S.-L., Lee, H.-Y. (2001) "Are Current Account Deficits Sustainable? Evidence from Panel Cointegration", Economics Letters, Vol. 72, No. 2, pp. 219-224, doi: 10.1016/S0165-1765(01)00420-7.

Zivot, E., Andrews, D.W.K. (1992) "Further Evidence on the Great Crash, the Oilprice Shock, and the Unit-root Hypothesis", Journal of Business \& Economic Statistics, Vol. 10, No. 3, pp. 251-270, doi: 10.2307/1391541. 


\title{
Intertemporalna održivost tekućeg računa platne bilance u prisutnosti strukturnih lomova ${ }^{1}$
}

\author{
Miomir Jakšic ${ }^{2}$, Nikola Fabris ${ }^{3}$, Milutin Ješic ${ }^{4}$
}

\begin{abstract}
Sažetak
Istraživali smo hipotezu o održivosti bilanci tekućeg računa u Češkoj, Mađarskoj, Poljskoj i Srbiji. Naša motivacija za ovo istraživanje proizlazi iz nedostatka koje smo uočili u sličnim studijama koje obuhvaćaju ove zemlje u promatranom razdoblju. Ovo je važno za analizu posljedica recentne globalne krize. Osnova za istraživanje može se naći u Hakkio \& Rush (1991.) i Husted (1992.). Međutim, u ovom smo radu koristili različite metodološke alate $s$ ciljem uključivanja mogućnosti strukturnih lomova. Ideja vodilja bila je empirijski testirati održivost tekućeg računa platne bilance kroz koncept kointegracije između izvoza i uvoza. U posljednjim desetljećima postignut je značajan napredak $u$ ekonometrijskom modeliranju, što je pokazalo da zaključci izvedeni iz standardnih testova mogu biti nepouzdani u prisutnosti strukturnih lomova. Cilj je provjeriti tu hipotezu primjenom novih pristupa. Testovi jediničnog korijena primijenjeni su na promatrane varijable. Nakon toga je upotrijebljen Gregory-Hansen pristup kako bi se ispitalo postojanje kointegracije. Konačno, procijenili smo kointegracijske vektore. Glavni nalaz istraživačke studije je da u svim promatranim zemljama postoji neki oblik održivosti tekućeg računa platne bilance. U Češkoj i Mađarskoj stupanj održivosti tekućeg računa je veći, dok je u Poljskoj i Srbiji niži. Stoga, kreatori politike moraju značajno poboljšati konkurentnost s ciljem održavanja vanjske stabilnosti. Ovaj rad proširuje postojeću literaturu, budući da se koriste novi metodološki okviri i analizirane su nove zemlje ili novi vremenski periodi.
\end{abstract}

Ključne riječi: tekući račun, intertemporalni pristup, strukturni lomovi

JEL klasifikacija: C13, F32, F41

1 Ovaj rad je podržan od strane Ministarstva znanosti, prosvjete i tehnološkog razvoja Republike Srbije u okviru projekta "Uloga države u novom modelu rasta srbijanskog gospodarstva" (179065).

2 Redoviti profesor, Univerzitet u Beogradu, Ekonomski fakultet, Kamenička 6, 11000 Beograd, Srbija. Znanstveni interes: makroekonomska teorija i institucije. Tel.: +381113021079. Fax: +381112639560. E-mail: mjaksic@ekof.bg.ac.rs. Osobna web stranica: http://www.ekof.bg. ac.rs/miomir-jaksic-phd/?lang=en.

${ }^{3}$ Redoviti profesor, Univerzitet u Beogradu, Ekonomski fakultet, Kamenička 6, 11000 Beograd, Srbija. Znanstveni interes: makroekonomska teorija i monetarna politika. Tel: +381113021086. Fax:+381112639560.E-mail:fnikola@ekof.bg.ac.rs. Osobnaweb stranica: http://www.cbcg. me/slike_i fajlovi/fajlovi/html/nikola_fabris.html.

4 Asistent, Univerzitet u Beogradu, Ekonomski fakultet, Kamenička 6, 11000 Beograd, Srbija. Znanstveni interes: makroekonomska teorija i politika. Tel.: +381113021097. Fax: +381112639560 . E-mail: milutinjesic@ekof.bg.ac.rs. Osobna web stranica: http://www.ekof.bg.ac.rs/milutinjesic/?lang=en (osoba za kontakt). 


\section{Appendices}

\section{Data series}

\section{Import variable modification}

Before presenting the series on which we have applied the proposed methodology, we will briefly explain modification of the import series. As stated in the main part of the paper, variable import should be modified in accordance to the theoretical postulates in order to include the effects of net factor income and net unilateral transfers. This is done based on the formula stated in the main part of the paper. In the following figures we will present the effects of the modification of original import series.

Figure A1: Modified import and it's components in Czech R. (seasonally nonadjusted data)

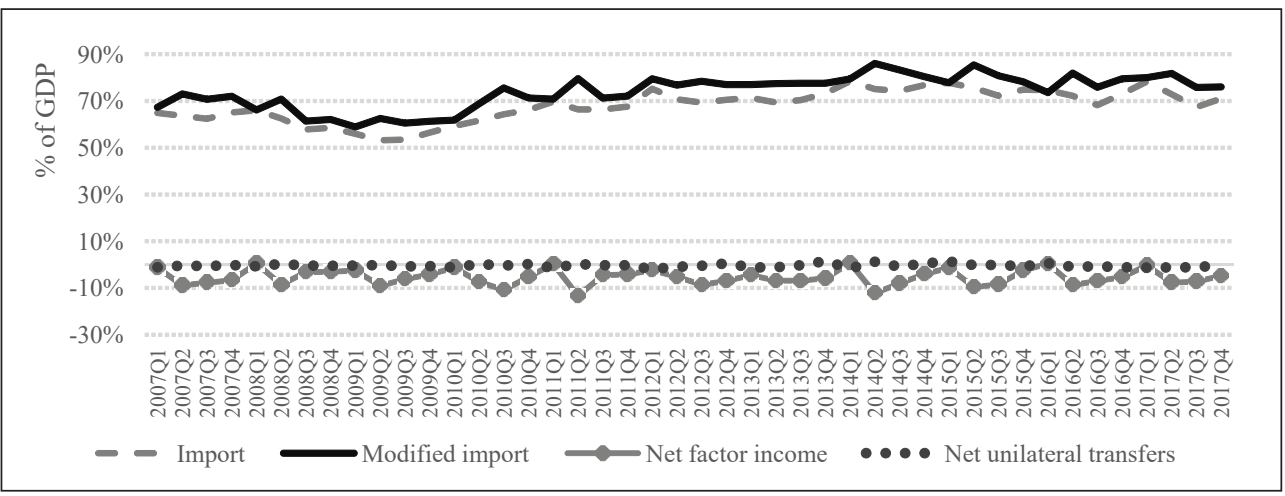

Source: Eurostat <http://ec.europa.eu/eurostat $>$

Figure A2: Modified import and it's components in Hungary (seasonally nonadjusted data)

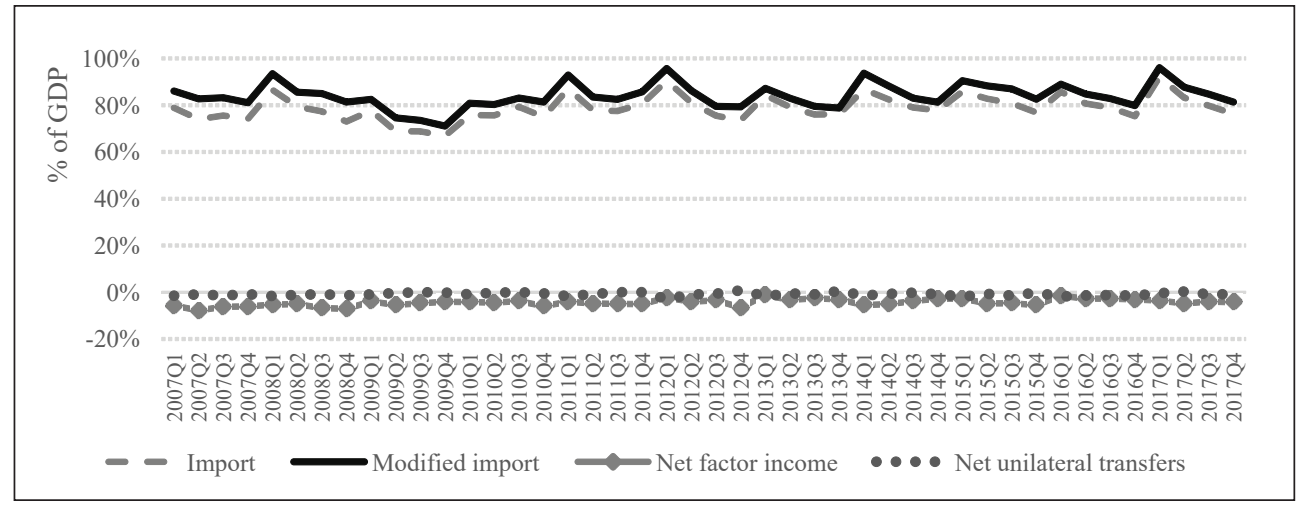

Source: Eurostat $<$ http://ec.europa.eu/eurostat $>$ 
Figure A3: Modified import and it's components in Poland (seasonally nonadjusted data)

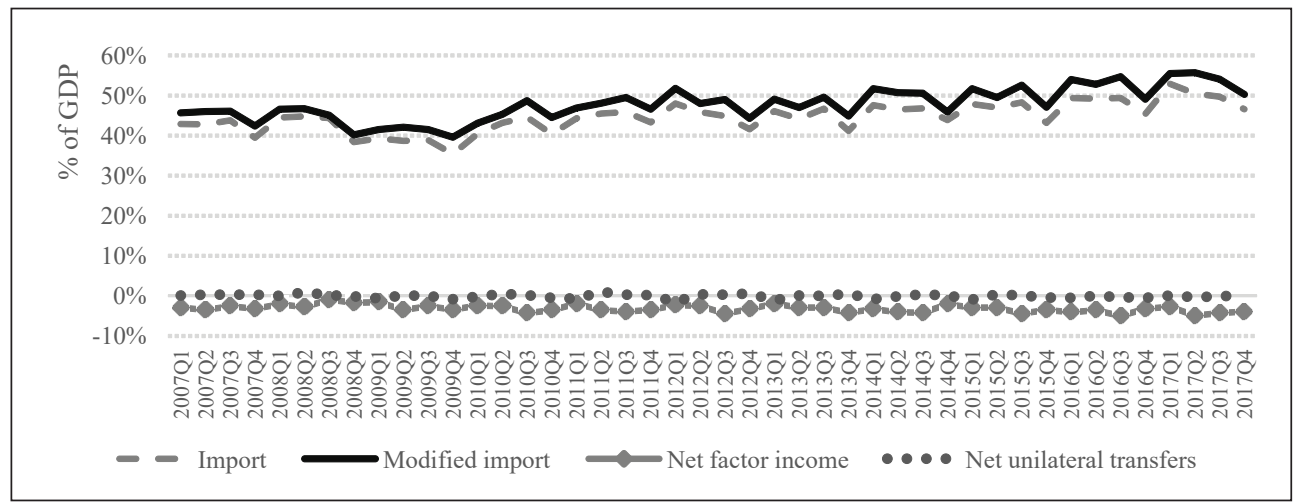

Source: Eurostat $<$ http://ec.europa.eu/eurostat $>$

Figure A4: Modified import and it's components in Serbia (seasonally non-adjusted data)

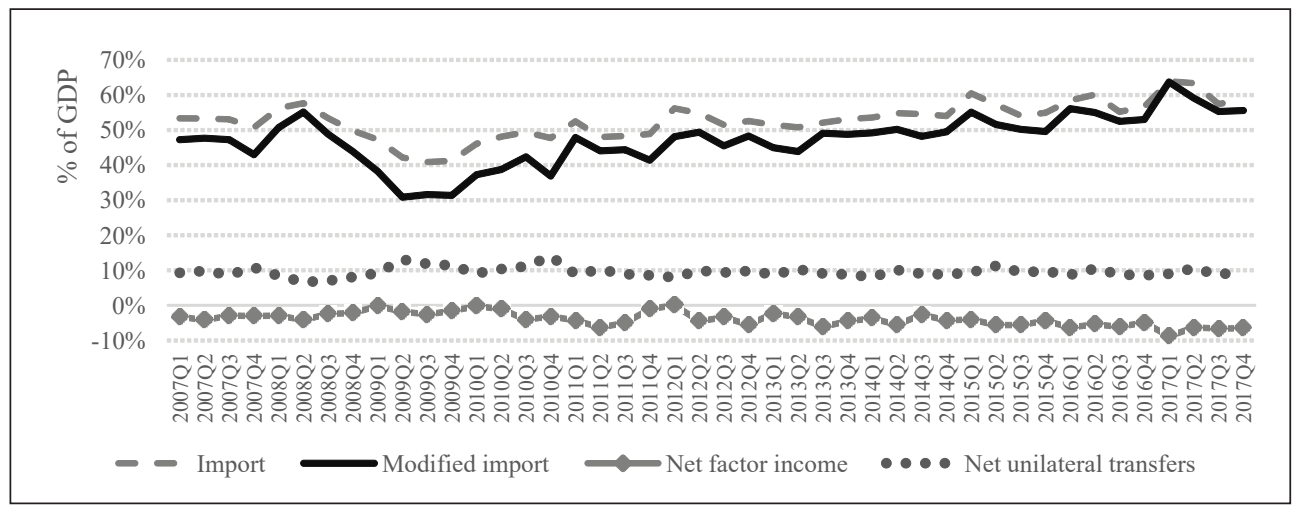

Source: Eurostat $<\mathrm{http}$ ://ec.europa.eu/eurostat $>$

As can be seen from the figures, the series of import and modified import are different for the margin that emerges from net factor income and net unilateral transfers corrections. However, the sign and value of the margin differs among the countries. All countries have higher outflows than inflows related to the factors' income over the most period of time. This has adverse effect on the CA sustainability, since it increases the gap between modified import and import. In addition, Czech Republic, Hungary and Poland have slightly higher outflows than inflows related to the unilateral transfers in the most periods of time. Contrary, Serbia has higher inflows all the time. In addition, this margin is very high in the case of Serbia. The reason for this divergence from the rest of the observed countries can be found in the fact that 
Serbia is one of the countries with highest remittances in the Europe. The level of remittances inflow in Serbia is usually around 8\% of GDP, and sometimes it is even above $10 \%$. This is one of the main factors of Serbia CA sustainability. Therefore, modified import series in Serbia is lower than original import series, because of the positive effects of much higher inflows than outflows related to the unilateral transfers. In other words, negative gap between the export and import is narrowed by net positive inflows related to the transfers. In the rest of the observed countries the modified import is higher than original import series. By this modification, we prepared data for the subsequent steps in the process of analysis.

\section{Data used in the analysis}

Figure A5: CA balance in \% of GDP (de-seasonalized data)

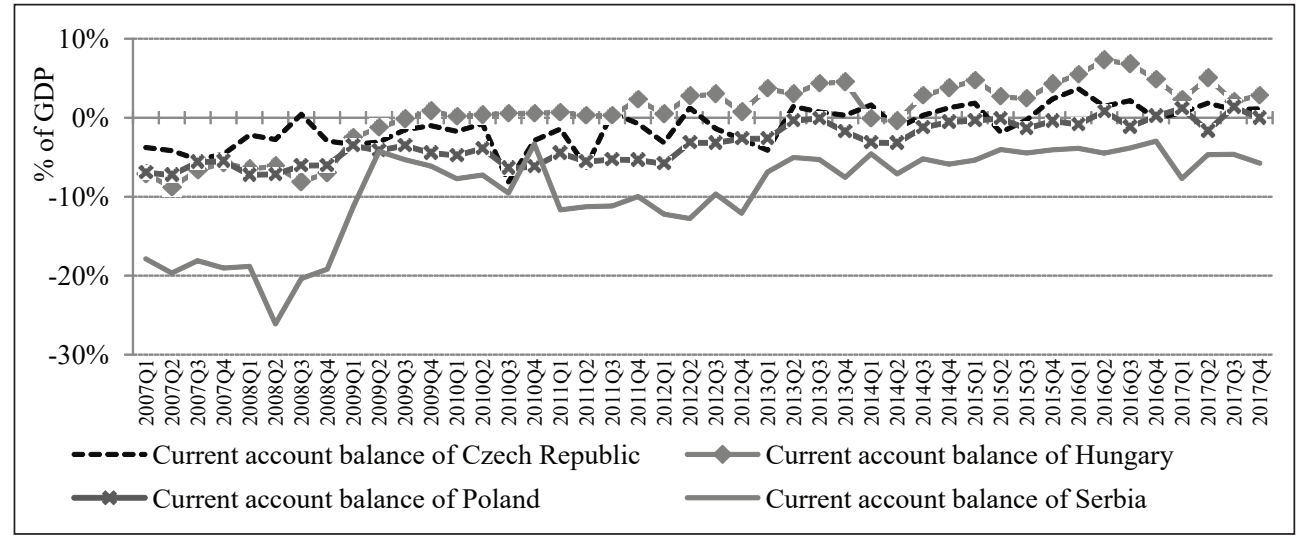

Source: Authors' calculations

Figure A6: Export and import of Czech Republic in \% of GDP (de-seasonalized data)

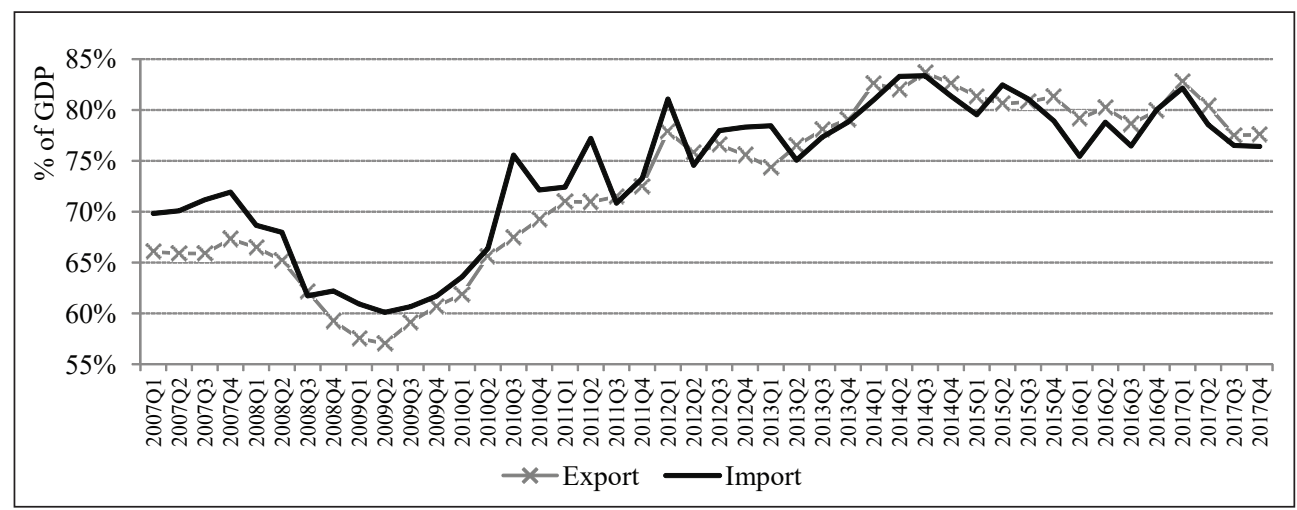

Source: Authors' calculations 
Figure A7: Export and import of Hungary in \% of GDP (de-seasonalized data)

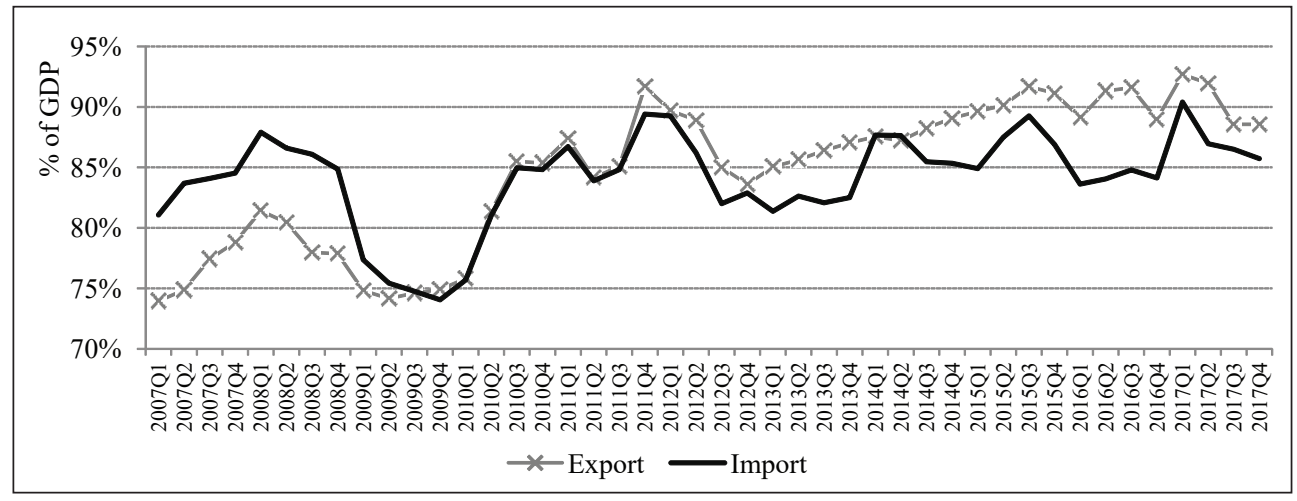

Source: Authors' calculations

Figure A8: Export and import of Poland in \% of GDP (de-seasonalized data)

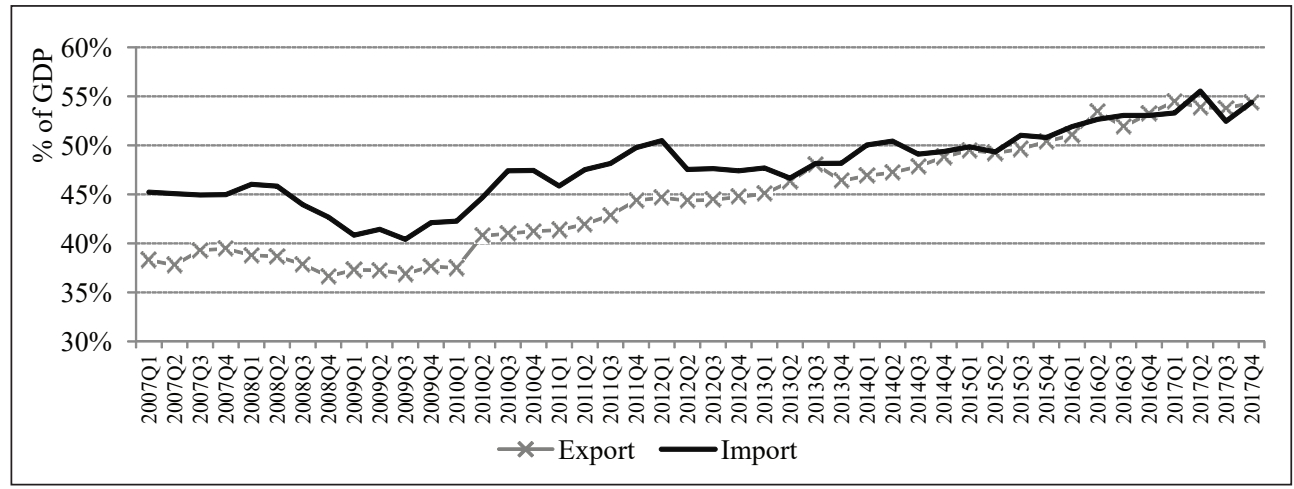

Source: Authors' calculations

Figure A9: Export and import of Serbia in \% of GDP (de-seasonalized data)

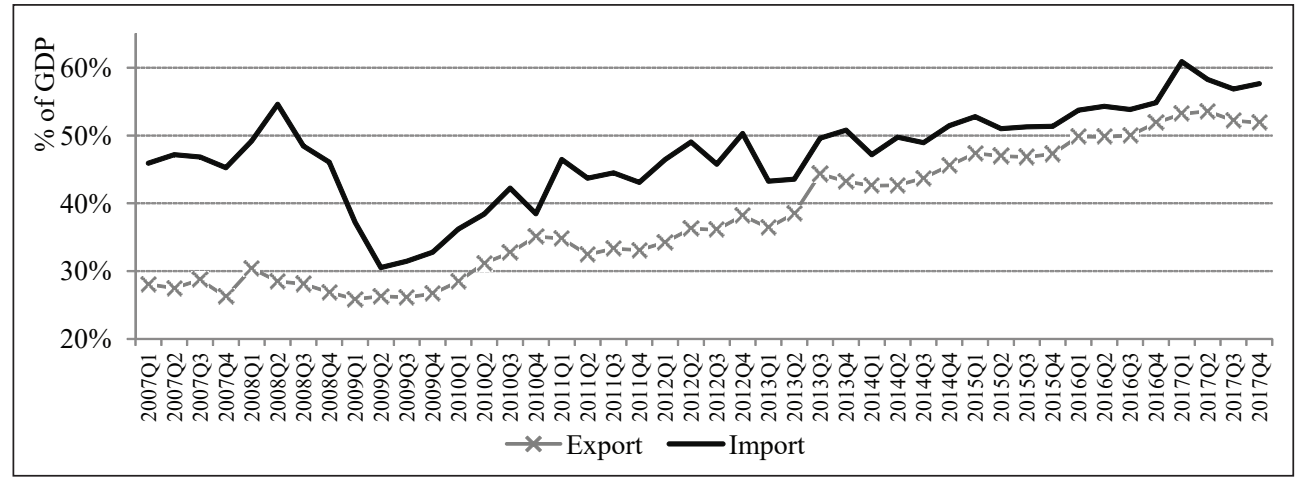

Source: Authors' calculations 


\section{Tests}

For the purpose of the justification of the unit root test modalities usage, with attention to inclusion of different deterministic components, we present formal test results. We decided to use a specific form of the tests based on the following formal test and on the visual examination of the series. Next table shows a summary of the results of the Stock-Watson test. We can conclude that when testing the presence of unit roots in these series, it is necessary to use both constant and trend as deterministic components. In contrast with that, following the results of this test, we used only constant in other cases. In the case that series are trend-stationary when the most comprehensive test is used, then we did not carry Stock-Watson test.

Table A1: Stock-Watson test of the adequacy of deterministic components

\begin{tabular}{|c|c|c|c|c|}
\hline Country & Variable & Coefficient c & t value & p value \\
\hline \multirow{3}{*}{ Czech R. } & Export & 0.2675 & 0.7524 & 0.4560 \\
\cline { 2 - 5 } & Import & 0.1534 & 0.3561 & 0.7236 \\
\cline { 2 - 5 } & Balance & & & \\
\hline \multirow{4}{*}{ Hungary } & Export & 0.3398 & 0.9891 & 0.3283 \\
\cline { 2 - 5 } & Import & 0.1085 & 0.2522 & 0.8021 \\
\cline { 2 - 5 } & Balance & 0.2313 & 1.0521 & 0.2988 \\
\hline \multirow{3}{*}{ Poland } & Export & 0.3731 & 2.9871 & 0.0047 \\
\cline { 2 - 5 } & Import & 0.2134 & 1.1221 & 0.2682 \\
\cline { 2 - 5 } & Balance & \multicolumn{3}{|c}{} \\
\hline \multirow{3}{*}{ Serbia } & Export & 0.5544 & 2.5088 & 0.0161 \\
\cline { 2 - 5 } & Import & 0.2726 & 0.5264 & 0.6014 \\
\cline { 2 - 5 } & Balance & 0.2818 & 0.6796 & 0.5005 \\
\hline
\end{tabular}

Notes: Blank cells indicate that test was not employed due to the algorithm of testing, i.e. series were trend-stationary.

Source: Authors' calculations 
Table A2: Results of the ADF test

\begin{tabular}{|c|c|c|c|c|c|c|}
\hline & \multirow[b]{2}{*}{$\begin{array}{l}\text { Deterministic } \\
\text { components }\end{array}$} & \multicolumn{2}{|l|}{ Level } & \multicolumn{2}{|c|}{ First difference } \\
\hline & & & $\begin{array}{c}\text { Estimated } \\
\mathrm{ADF}(k) \text { statistic }\end{array}$ & Lags & $\begin{array}{c}\text { Estimated } \\
\operatorname{ADF}(k) \\
\text { statistic }\end{array}$ & Lags \\
\hline \multirow{3}{*}{ Czech R. } & Export & constant & -0.8869 & 0 & $-5.1830 *$ & 0 \\
\hline & Import & constant & -1.6072 & 0 & $-8.0138^{*}$ & 0 \\
\hline & Balance & constant, trend & $-6.6086^{*}$ & 0 & & \\
\hline & & & & & & \\
\hline \multirow{3}{*}{ Hungary } & Export & constant & -1.8687 & 0 & $-5.8680^{*}$ & 0 \\
\hline & Import & constant & -2.4118 & 0 & $-5.6402 *$ & 0 \\
\hline & Balance & constant & -2.0237 & 0 & $-7.3608^{*}$ & 0 \\
\hline & & & & & & \\
\hline \multirow{3}{*}{ Poland } & Export & constant, trend & -2.8869 & 0 & $-7.6198 *$ & 0 \\
\hline & Import & constant & -0.6099 & 0 & $-7.0660 *$ & 0 \\
\hline & Balance & constant, trend & $-4.3954 *$ & 0 & & \\
\hline & & & & & & \\
\hline \multirow{3}{*}{ Serbia } & Export & constant, trend & -2.8627 & 1 & $-4.8315^{*}$ & 1 \\
\hline & Import & constant & -1.2438 & 1 & $-6.8979 *$ & 0 \\
\hline & Balance & constant & -1.9879 & 1 & $-8.2241 *$ & 0 \\
\hline
\end{tabular}

Notes: * ** and *** Denote significance at $1 \%, 5 \%$ and $10 \%$, respectively.

Lag lengths are based on SIC; Critical values are based on MacKinnon (1991).

Source: Authors' calculations 
Miomir Jakšić, Nikola Fabris, Milutin Ješić • Intertemporal current account...

Table A3: Results of the KPSS test

\begin{tabular}{|c|c|c|c|c|c|c|}
\hline & & \multicolumn{2}{|c|}{ Level } & \multicolumn{2}{|c|}{ First difference } \\
\hline & & $\begin{array}{l}\text { Deterministic } \\
\text { components }\end{array}$ & $\begin{array}{c}\text { Estimated } \\
\text { LM } \\
\text { statistic } \\
\end{array}$ & Bandwidth & $\begin{array}{c}\text { Estimated } \\
\text { LM } \\
\text { statistic }\end{array}$ & Bandwidth \\
\hline \multirow{3}{*}{ Czech R. } & Export & constant & $0.6785 * *$ & 5 & 0.1339 & 3 \\
\hline & Import & constant & $0.5887 * *$ & 5 & 0.0956 & 3 \\
\hline & Balance & constant, trend & 0.0510 & 1 & & \\
\hline \multirow{3}{*}{ Hungary } & Export & constant & $0.7189 * *$ & 5 & 0.1045 & 0 \\
\hline & Import & constant & $0.8653 *$ & 0 & 0.0435 & 0 \\
\hline & Balance & constant & $0.7020 * *$ & 5 & 0.2132 & 7 \\
\hline \multirow{3}{*}{ Poland } & Export & constant, trend & $0.4055^{*}$ & 0 & 0.0529 & 0 \\
\hline & Import & constant & $0.7151 * *$ & 5 & 0.1116 & 2 \\
\hline & Balance & constant, trend & 0.0714 & 3 & & \\
\hline \multirow{3}{*}{ Serbia } & Export & constant, trend & $0.1598 * *$ & 4 & $0.1263 * * *$ & 7 \\
\hline & Import & constant & $0.5313^{* *}$ & 5 & 0.0992 & 2 \\
\hline & Balance & constant & $0.5903 * *$ & 5 & 0.0772 & 4 \\
\hline
\end{tabular}

Notes: $* * *$ and $* * *$ Denote significance at $1 \%, 5 \%$ and $10 \%$, respectively.

The critical values are based on Kwiatkowski et al. (1992)

Source: Authors' calculations 
Miomir Jakšić, Nikola Fabris, Milutin Ješić • Intertemporal current account... Zb. rad. Ekon. fak. Rij. • $2018 \cdot$ vol. $36 \cdot$ no. $2 \cdot 413-442$
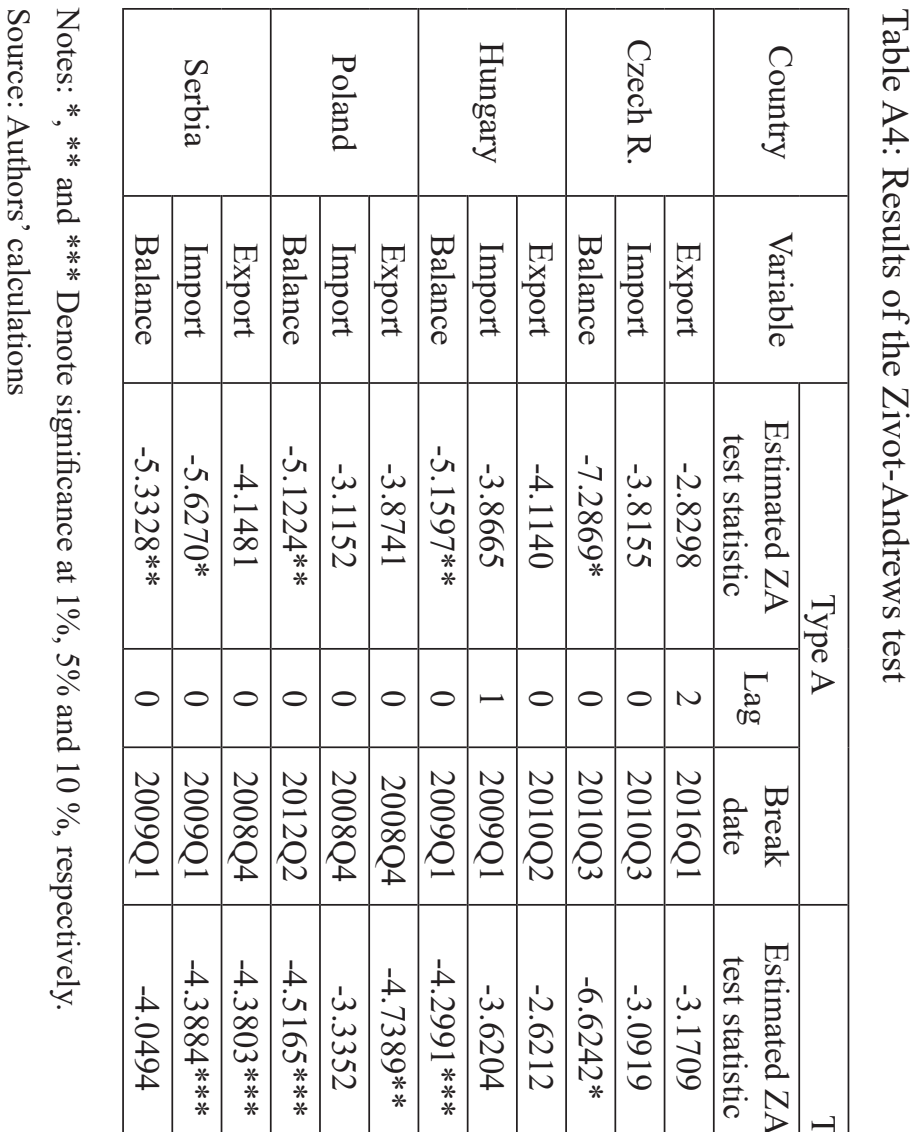